\title{
EXPLORING HOW ENGLISH LANGUAGE TEACHERS IN PRIMARY SCHOOL CONSTRUCT THEIR PROFESSIONAL IDENTITIES
}

\author{
Melkamu Teklu Kisi ${ }^{1} \bowtie$ \\ ${ }^{1}$ Addis Ababa Science and Technology University P.O.B 16417, Addis Ababa, Ethiopia
}
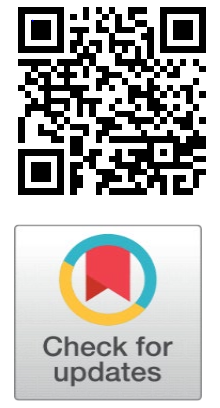

Received 04 January 2022

Accepted 05 February 2022

Published 28 February 2022

\section{CorrespondingAuthor}

Melkamu Teklu Kisi,

malkekoo@gmail.com

DOI 10.29121/ijetmr.v9.i2.2022.1024

Funding: This research received no specific grant from any funding agency in the public, commercial, or not-for-profit sectors.

Copyright: (C) 2022 The Author(s). This is an open access article distributed under the terms of the Creative Commons Attribution License, which permits unrestricted use, distribution, and reproduction in any medium, provided the original author and source are credited.

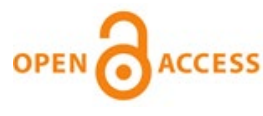

\section{ABSTRACT}

This study explores how English Language teachers in primary school construct their professional identities (PI) as English teachers. Teacher interview was uses as a data gathering tools for the study. Accordingly, ten English language teachers who were teaching English in upper primary schools were interviewed to collect data needed. The results of the interview data reveal that former English as FLT willingness to help students learn well, good teaching skills, students' engagement, the understanding that schools as a safe learning environment, and teacher confidence and competence were honored by EFL to construct their profession identities. Similarly, teachers' commitment, sense of appreciation and self-understanding, sense of connectedness, and imaging future career were also honored to develop teacher professional identity. The teacher interview data imply that the English teachers are required to professionally develop the willingness to help students learn well, to develop the motivation needed to engage students to increase their classroom practices. Based on the findings of the study, it was suggested that UPSET is also required to get further development programs so that they develop their knowledge and pedagogic skills needed to create a safe learning environment and to their increase confidence and competence needed to teach this grade level students.

Keywords: Professional Identity, Professional Development, Identity Construction

\section{INTRODUCTION}

Teaches' professional identity construction (TPIC) is dynamic in its nature Beijaard et al. (2004). These scholars indicate teacher development is a long-lasting process addressing not only 'Who am I' but also 'who do I want to be in the future?' Lasky (2005) holds a similar opinion when he discusses TPIC is referred to as who the teacher is/will be in the community. A study by Beijaard et al. (2004) point out that teacher professional identity construction is how teachers define themselves to themselves and how they define themselves to others. Beijaard and associates state that teachers interact with other teachers of different identities which would influence 
them to change their identities over time. Similarly, in social interactions, selfunderstanding can be developed by controlling our and other people's roles Atay and Ece (2009). Corroborating this, Beijaard et al. (2004) reported that being a teacher thus means how the person sees himself or herself and how others see the person who shows that identity in a socially, culturally, and contextually constructed phenomenon.

Socially, culturally, and contextually constructed teachers share their experiences with each other to improve and develop professionally Beijaard et al. (2004). They pointed out that experience sharing with each other was an important source of teachers' professional identity construction. They stated English teacher identity construction is impacted by prior teaching and learning and sharing experiences. Clarke (2008) holds a similar opinion in stating that teaching experiences and sharing of knowledge play key role in teacher development. That means sharing of knowledge helps them construct their professional identities as English teachers. This finding is consistent with the results of Arsla (2019) whose study reveals the teachers gradually construct their professional identity through improving their teaching practices to enhance their professional development. Hasan and Shadi (2019) hold a similar opinion when they state teacher professional identity construction took place during experience sharing which can be regarded as social activity wherein the teachers found the opportunity to share their views and ideas with colleagues

A study by Loughran (2004) exposed that attending self-study conferences and workshops helps teachers construct their professional identities. This means selfstudy represents an increasingly popular approach in teacher research that aims to increase understanding of oneself, teaching, learning and development of knowledge. Likewise, Guilfoyle et al. (1995) hold a similar opinion when they state that teacher is shedding light on their own professional learning experiences through self-study of their practices. Wenger (1998) points out that there is interrelationship between professional learning and identity. This means that professional learning is a social process that takes place within communities of practice. Wenger argued that learning and identity are inseparable and that both are essentially social constructs.

This finding is consistent with the results of Farrel (2011) whose study shows that when teachers participate in different professional development activities, they build and rebuild the image of themselves. Farrell states that teachers' professional identity is developed by participating in professional development activities and is shaped through exposure to various discourses inside and outside classes.

Mitchell (1997) describes that teachers' collaboration with colleagues during professional development activities is among the key factors for the teachers' professional identity construction. Doing so might lead to self-awareness and selfdevelopment (as English language teachers). Gee (2000) holds a similar opinion in stating that observations and experience sharing from experienced teachers contribute to teachers' professional identity construction. This means that when teachers sit together and share ideas on their profession, teachers share knowledge to grow professionally and construct their identities greatly. This finding can be further supported by McLaughlin and Talbert (1993) whose study reveals teacher need to participate in professional activities: peer coaching, action research, observation and reflection and case discussion. Their participation in observation and experience sharing would help them to develop their professional identities. 
Wenger (1999) teachers' professional identity is developed through participating in different day-to-day activities. This means that teachers are required to sit together and discuss issues they have in common, their passions about topics and their experts in an area. This result is consistent with those of Wenger (1998) with which participants in multiple communities of practice often make connections between communities. These practices are significant because they contribute to the negotiation of new meanings within the respective communities. The nature of practice in these circumstances also changes, as interactions and connections enable new ways of learning and new practices to emerge. This enables identities of teachers to be constructed and modes of belonging to be strengthened. This finding is consistent with those of Mitchell (1997) whose finding indicated that teachers' collaboration with other colleagues was among the key factors for teacher professional identity construction.

Schultz and Ravitch (2013) were also consistent with this finding. They also conclude that teachers' professional identities were formed by being involved in different professional community and different activities which eventually lead to their professional identity construction. Schultz and Ravitch (2013) state that classroom experiences include exposure to teaching methods, the curriculum, and the classroom climate emerging by the nature of interactions. Student characteristics, teaching practices and classroom climate have a unique contribution on teacher professional development. This idea is consistent with that of Wenger (2000) whose finding reveals discussing professional development activities are used to construct professional identities of teachers and strengthens their and modes of belonging to be strengthened. Wenger believed that learning communities have particular characteristics that enable the creation of new knowledge.

Wenger (2000) states that teachers come together with other members to participate in their own development opportunities and empower them to fully realize their professional identities. This means their participation on professional development activities strengthen teachers' professional identities because it incorporates their past learning and existing knowledge into the practices of the community.

Teacher professional identity has been theorized by many scholars, like (e.g., Wenger, 2000, Urzúa and Vásquez (2008), Luehmann (2007), Forbes and Davis, 2007, Beijaard et al. (2004). Similarly, Goodson and Cole (1994) explored identity development of college teaches with no preparation, and Mawhinney and Xu (1997) studied foreign-trained teachers' identity development in the UK. Some researchers, however, have specifically studied aspects of identity development among teachers, such as Maor and Taylor (1995), who examined science teachers" beliefs about the nature of learning as they related to incorporating technology during inquiry teaching. Besides, Goodman (1988) conducted a study on constructing a practical philosophy of teaching. Guilfoyle et al. (1995) studied on becoming teachers of teachers, Guskey (2010), Professional Development and Teacher Change and Hasan and Shadi (2019) studied on ELF teachers' Identity Construction through a Reflection Consciousness.

Although these exploratory studies provide some information for teacher identity construction, Volkmann and Anderson (1997) note, specific knowledge of how English language teachers in upper primary school construct professional identities is scarce. The present study was motivated to fill this gap.

In order to help us understand potential problems and fill the research gap in English teacher identity development in upper primary schools, exploring how an 
English language teachers construct their professional identities is vital. Despite the fact that numerous studies have investigated the various aspects professional development of teachers, a plethora of research on teachers' professional identity construction has not yet been done. This means that many of the studies so far have not focused on exploring how the English language teachers construct their PI as English teachers. Put shortly, there is little or no empirical research has devoted to study how teacher develop their professional identities. The present study was motivated to explore the EFL teachers construct their professional identity as English language teachers in upper primary schools.

\section{OBJECTIVE OF THE STUDY}

The general objective of this study is to explore how English language teachers in upper primary school construct their professional identities.

\section{RESEARCH QUESTION}

The present study was used to address the following research question.

How do English language teachers in upper primary schools construct their professional identities as teachers?

\section{PARTICIPANTS}

Potential participants were English language teachers in upper primary schools found in North Showa Zone of Oromia Regional State in Ethiopia. Eight teachers who were teaching English at the time of data collection were randomly selected for the purpose of data collection. The data were collected in the 2020/2021 Academic years. The purpose of the study was informed to the respondents and their participation was voluntary.

\section{DATA COLLECTION}

Teacher interview was used to gather data on how the English language teachers in upper primary schools construct their professional identities as teachers. Teacher interview was used as a data gathering tool Birks and Mills (2011). The teacher interview was used to gather teachers' ideas on how they construct their professional identities as teachers.

The interviewed English teachers were coded as T1, T2, T3, T4, T5, T6, T7, T8, T9 and T10. The codes were given to the interview respondents. The interviews lasted between 30 and 40 minutes. The nature of the interview was flexible, and the interview questions were paraphrased, and prompts were made to allow participants to provide the most genuine responses when expressing their opinions King and Horrocks (2010).

\section{DATA ANALYSIS}

After the interviews were conducted and transcribed, the data analysis process went through several stages, following the principles of Grounded Theory Birks and Mills (2011). First of all, a thorough process of reading the whole interview 
transcripts were held. This process allowed the data to be broken down into different parts and be coded. These initial codes were refined and reorganized from which themes were evolved. Then the themes evolved were developed.

All of the evolved themes from interviews involving teachers were then compared with each other's to identify underlying patterns. The results were distinctive categories which signify the themes emerging in the study Birks and Mills (2011). Following this was an examination of relationships between the overriding themes in order to develop the themes.

There were a few times during the analysis process when contradictory data were found, so data validation was achieved through the elimination of their relationships and the exploration of possible alternative explanations within other categories Dey (2004). The process of data analysis continued until theoretical saturation was reached; that is, when probes for categories and properties in final interview resulted in no further data modification Birks and Mills (2011). The outcome of this Grounded Theory analysis was a model that indicates a comprehensive ways of how English language teachers in upper primary schools construct their professional identities as teachers Glaser and Strauss (1967). Here under is the data collected from the study participants. To gather teachers' ideas on how they construct their PI, the interview question 'Why did you choose to become a teacher?' was asked. The responses obtained from the teacher responses served as evidence of how they construct their professional identities as English teachers.

Below is an extract taken from Teacher 1 responses to the question: Why did you choose to become a teacher?

The best teacher I ever had was my English teacher in elementary school. I preferred English because of her. She walked around the class to help us understand her lessons. Furthermore, when she taught English, she knew her subject well and used an easy method to make her lessons clear to the students. I was inspired by her teaching techniques and knowledge of the subject, and I strive to bring the same passion to my classroom.

In response to the same question, $\mathrm{T} 2$ had to say the following:

My third-grade English language teacher was a real inspiration to me, and he was one of the major reasons I pursued a teaching career and finally I become an English language teacher. The teacher taught me from grades 3-6. I appreciated his knowledge of English. His ability to guide students, his fairness, and his good habits has inspired me to become an English language teacher.

When asked the same question, Teacher 3 had to say this:

I chose to be a teacher because teaching is free from any politics. I go to school; I teach and go back to my home. This is my mission. Teaching is molding children. That means I as a teacher play a key role in molding and shaping. Help them in any way you can. The destiny of my students is shaped in classrooms.

Below is Teacher 4's response when asked the same question:

Teaching is a job which always renews life. I love teaching; it gives me chances to learn lessons, teach new topics, and work with new children each year.

Below is an extract taken from Teacher 5 in response to the question: Why did you choose to become a teacher?

When I was a student, I was convinced that teachers must stay on top of new technologies, trends, and historic events, ensuring I will always be learning 
something new and impart this new lesson to my students to help them gain the knowledge that will help them shape the next generation.

Below is an extract taken from Teacher 6 in response to the same question:

Teaching is an exchange of knowledge and a highly transferable skill. I strongly believe if I am trained to become a qualified teacher, I will be able to work pretty much anywhere in the world. Teaching English has these opportunities, and I can work and explore at the same time. International schools are growing in number all over the world and many are looking favorably upon English teachers who have trained and qualified in English.

Below is Teacher 7's response when asked the same question:

Despite the small amount of money, we are paid, another bonus for many teachers is the chance to work in a social atmosphere. Teaching profession is an enjoyable profession as we work as part of a team with our colleagues, while interacting with students each day. We help students to reach their goals and also, we help each other. Teachers have the opportunity to become an integral part of the community, getting to know parents and community members.

Below is Teacher 8's response when asked the same question:

Teaching offers far more than just entering class and teaching English. As a teacher I will have a satisfying career, knowing that I have made a difference in many lives. Through interacting with students and community members from a range of different backgrounds, I will gain greater understanding of the society and flex my creative skills. Teaching is also a good chance to grow personally and professionally.

In response to the same question, T9 was quoted saying:

I was inspired by my grade one English language teacher. She taught English very well. I admire her knowledge of the subject and the way she treated and approached the children. She used the easiest ways to the class to make the lessons clear. Her kindness and willingness inspired me much. Her passion to bring innovative ways and method of teaching inspired me to a teacher.

T10 was question saying:

My seventh-grade English teacher was the main reason for my choice of being EFL teacher. Besides, I was also taught by a clever English language teacher. When I was lower grade school student, both the teacher had good qualities of a teacher. Their knowledge and teaching methods motivated me to be like them.

So far, the interview data obtained in response to the Research Question (why the study participants chose to become English language teachers?) have been reported. In the next section, themes that have evolved from the study participants' responses was brought together and analysed. The analysis would give us evidence of why the study participants chose to become English language teachers. The evidence would serve us the sources of how the English language teachers construct their professional identities as teachers.

\section{FINDINGS OF THE STUDY}

The findings of the study are presented according to the themes evolved from the data. The themes evolved are teachers' willingness to help students learn well, knowledge of the subject, good teaching skills, teachers' motivation and students 
Engagement and teachers' competence and confidence. These would serve us as sources of teacher identity construction.

\subsection{WILLINGNESS TO HELP STUDENTS LEARN WELL}

One significant theme evolved from the responses was teachers' willingness to help students well. The interview participants considered their former teachers' willingness to help them learn well as an influencing factor for choosing a teaching profession. Former teachers' willingness to help students learn well created interest in the respondents to become English teachers. A study by Barbour and Lammers (2015) reveal that teachers' willingness to help students learn well one of the sources which helps them develop their professional identities as teachers. According to them teachers' professional identity is rapidly developing when the teachers have the willingness to help their students learn well.

Most interviewed participants had one or more teachers who they said were willing to help their students learn well. The implication is they want to be professionally developed. The interview participants also recalled their former teachers' willingness to help them learn well and this impacted their choice of a teaching profession. This means that the respondents were inspired by the teachers' willingness to help them learn well. This implies that their former teachers' willingness to help influenced what the participants choose to become. The implication may mean that the teachers need CPD which develops their whole personality (willingness to help other, for example). The implication of this might mean that the teachers need the linguistic potential to help their students. Their needed linguistic capability can develop through attending CPD development program

\subsection{TEACHERS' KNOWLEDGE OF THE SUBJECT}

Another significant theme that can be drawn from the teachers' responses to why they chose to become English teachers is their former teachers' subject matter knowledge. Teachers' knowledge of the subject was honored by the respondents Zein (2017). This means that respondents' former teachers' knowledge of the subject was one of the key factors that influenced the respondents' choice. All the interview participants replied that their former teachers' knowledge of the subject created interest in them to choose teaching as their careers. High quality teaching rests on teachers' subject matter knowledge. Sparks (2002) holds a similar opinion when he discusses that teachers are required to develop their content knowledge and the teaching skills in order to increase students' achievements. The interview data also clearly confirms this. This might mean students are motivated to choose teaching as their careers when their former teachers have good knowledge of the subject they were teaching. An implication of this can be found in the respondents need to become more knowledgeable in the subjects they are teaching.

\subsection{GOOD TEACHING SKILLS}

Another theme shared across the respondents' during the interview about why they chose teaching profession was teachers' good teaching skills. This means the techniques used by the respondents' former teachers to teach English influenced respondents' career choices. This means the respondents honored their former teachers' teaching strategies because the strategies changed their life and formed 
their values. This finding is further supported by Clarke (2008) who points out that good teachers' skills is one of the professional development areas that the teachers are required to develop professi0nally. Fekede and Pavi (2015) also hold a similar opinion when he states that teachers teaching skill is one of the main skills the teachers are required to have. The implication of this was clear. They need to become more skillful English teachers. Developing their profession enables them to achieve this.

\subsection{TEACHER MOTIVATION AND STUDENTS' ENGAGEMENT}

The motivation the former teacher had for teaching and their engaging students in learning activities is another theme evolved from the interview data. Students in the classroom may have different motivation for learning. Activities teacher design should address students' motivation and engage them learning. The present respondents' former English teachers were reported to be successful in this regard. This means that the motivation to become English teachers arose from the respondents' recognition of this. This may imply that the respondents need to be more aware about ways students could be engaged activities and ways to design engaging activities for students.

The interview data reveal teacher motivation and students' engagement were the bases for the respondents' identity development. This means that respondents' professional identity is developed and sustained by teacher motivation and student engagement. The teachers are the most important professionals for any nation's future. This means motivated teachers create adequate support and resources for the students and play key roles in the respondents' choice of careers. Observing this might help learners to be motivated and engaged and get inclined towards a teaching profession. One should bear in mind that a nation's strength depends on the high quality of its education system and the strength, in turn, relies on motivated teachers. The implication of this might mean that the respondents want a program which enables them to be more motivated to help students. One source of motivation for the teachers is to help students in having developed linguistic and teaching skill resources.

\subsection{TEACHERS' CONFIDENCE AND COMPETENCE}

Another insightful theme evolved from interview data was teachers' confidence and competence. This means former teachers' confidence and competence were among the factors that influenced the respondents' choice of teaching as their career. This confidence and competence play key roles in the choices of participants teaching profession and this was what the study participants honored for their decision to become English teachers. The data reveal that their teachers' confidence and competence raised and sustained the respondents' identity construction Zein (2017). The implication of this for the present teachers' confidence and competence is clear. The respondents need to become more confident and more competent English teachers in upper primary schools. Developing their profession enables them to achieve this. 


\subsection{THE UNDERSTANDING OF A SCHOOL AS A SAFE WORK ENVIRONMENT}

Yet another theme that can be derived from the interview response is the understanding that school is a safe work environment. This means that the primary purpose of school is to educate children. Educating children is educating oneself for teachers. This is among what motivated the respondents to choose teaching. This funding can be further supported by Starkey et al. (2009) whose findings reveal that teaching in a safe environment give teachers the possibilities to construct their identities as teachers and expand their knowledge of the subject they are teaching.

Mitchell (1997) describes that teachers' collaboration with colleagues during professional development activities is among the key factors for the teachers' professional identity construction. According to Mitchell, a rational justification for this finding could be teachers' involvement in professional development activities and persistence for receiving others' ideas and points of views. Teachers' participation on professional development activities in their schools would help them construct their professional identities as teachers. This means that the teachers can develop and construct their professional identity when they participate in professional development activities. But one of the respondents disagreed teachers would construct their professional identity as teacher by participating in professional development activities in their schools. The implication might mean the value the value the respondents attach to making one's workplace safe and keeping oneself continually educated. The CPD they want should enable them to achieve this.

\section{CONCUSSIONS AND RECOMMENDATIONS}

In general, based on the data presentation and discussion made the following conclusions are given. It is suggested that English language teachers in upper primary schools in general and teacher identity construction in particular. The result of this research showed that the teachers require further development to be willing to help students learn well. It is also recommended that the teacher education institutions should prove the teachers with further professional development courses to enable them professionally. Being a teacher is influenced by key factors such as former teachers' good teaching skills, teacher competence and confidence. The key implication is that the teachers require further development program on this regard.

\section{REFERENCES}

Anderson R. D. (2002). Reforming science teaching: What research says about inquiry. Journal of Science Teacher Education, 13(1), 1-12. Retrieved from https://doi.org/10.1023/A:1015171124982

Arsla, Y. (2019). Reflection in Pre-service teacher education. Exploring the Nature Four EFl pre-service teachers' reflection. Reflective practice. Retrieved from https://www.tandfonline.com/doi/abs/10.1080/14623943.2018.156465 2

Atay, D., \& Ece, A. (2009). Multiple identities as reflected in English language education: The Turkish Perspective. Journal of Language, Identity and 


$\begin{array}{lcccc}\text { education } & 8(1), & 21-34 . & \text { Retrieved } & \text { from } \\ \text { https://doi.org/10.1080/15348450802619961 } & & \end{array}$

Beijaard, D., \& Meijer, P., Verloop, N. (2004). Reconsidering Research on Teacher professional identity. Teacher and Teacher Education 20 (2), 107-128. Retrieved from https://doi.org/10.1016/j.tate.2003.07.001

Birks, M. and Mills, J., (2011). Grounded theory : à practical guide. London : Sage Publications.

Clarke, M. (2008). Language Teacher Identities: Co-constructing Discourse and Community. Clevedon, Multilingual Matters. Retrieved from https://doi.org/10.21832/9781847690838

Dey, I., (2004). Grounded theory. In : C. Seale, G. Gobo, J.F. Gubrium and D. Silverman, eds. Qualitative research practice. London : Sage, 80-93.

Farrel, T. (2011). Exploring the professional development identities of experienced ESL through reflective practice, system, 39 (1), 54-62. Retrieved from https://doi.org/10.1016/j.system.2011.01.012

Fekede Tuli and Pavi, T. (2015). Professional Learning of teaches in Ethiopia: challenges and implications for reform. Australian Journal of Edcuation.

Gee, J. P. (2000). Identity a an Analytic Lens for Research in Education. Review of Research in Education, 99-125. Washington, DC : American Educational Research Association. Retrieved from https://doi.org/10.2307/1167322

Glaser, B.G. and Strauss, A. (1967). A discovery of grounded theory. Strategies for qualitative research. Chicago : Aldine Publication Company. Retrieved from https://doi.org/10.1097/00006199-196807000-00014

Goodman (1988). Constructing a practical philosophy of teaching: A study of preservice teachers" professional perspectives. Teaching and Teacher Education, 4, 121 Retrieved from https://doi.org/10.1016/0742051X(88)90013-3

Guilfoyle, K., Hamilton, M. L., Pinnegar, S. \& Placier, M. (1995) Becoming teachers of teachers : the paths of four beginners, in : T. Russell \& F. Korthagen (Eds) Teachers who teach teachers: reflections on teacher education (London, Falmer Press), 35-55.

Guskey, T. R. (2010). Professional Development and Teacher Change. Teachers and Teaching, 8(3), 381-391. Retrieved from https://doi.org/10.1080/135406002100000512

Hasan, S and Shadi, D. (2019). ELF teachers' Identity Construction through a Reflection Consciousness- Raising Interactive Workshop. International Journal of Society, Culture and Language.

King, N. and Horrocks, C., (2010). Interviews in qualitative research. London : SAGE. Publication.

Lasky, S. (2005). A sociocultural approach to understand teacher identity, ageny and professional vulnerability in a context of secondary reform. Teacher and teacher education 21(8), 899-916. Retrieved from https://doi.org/10.1016/j.tate.2005.06.003

Loughran, J. J. (2004) A history and context of self-study of teaching and teacher education practices, in : J. J. Loughran, M. L. Hamilton, V. K. LaBoskey \& T. Russell (Eds) International handbook of self-study of teaching and teacher 
education practices (Dordrecht, Kluwer), 7-39. Retrieved from https://doi.org/10.1007/978-1-4020-6545-3_1

Luehmann, A.L. (2007). Identity Development a a Lens to Science Teacher Preparation. Science Education, 91(5), 822-839. Retrieved from https://doi.org/10.1002/sce.20209

Maor, D. and Taylor, P.C. (1995) Teacher epistemology and scientific inquiry in computerized classroom environments. Journal of Research in Science Teaching, 32(8), 839-854. Retrieved from https://doi.org/10.1002/tea.3660320807

McLaughlin, M. W., \& Talbert, J. E. (1993). Contexts that matter for teaching and learning. Stanford, CA : Stanford University.

Mitchell, A. (1997). Teacher Identity. A key to increased collaboration. Action in Teacher education, 19 (3), 1-14. Retrieved from https://doi.org/10.1080/01626620.1997.10462875

Schultz, K., \& Ravitch, S. M. (2013). Narratives of learning to teach: Taking on professional identities. Journal of Teacher Education, 64(1), 35-46. Retrieved from https://doi.org/10.1177/0022487112458801

Sparks, D. (2002). Designing powerful professional development for teachers and principals. Oxford, OH : National Staff Development Council.

Starkey, L. M., Yates, A., Meyer, L. H., Hall, C., Taylor, M., Stevens, S. (2009). Professional development design : embedding educational reform in New Zealand. Teacher and Teaching Education, 25, 181-189. Retrieved from https://doi.org/10.1016/j.tate.2008.08.007

Urzúa, A., \& Vásquez, C. (2008). Reflection and professional identity in teachers' future-oriented discourse. Teaching and Teacher Education, 24(7), 19351946. Retrieved from https://doi.org/10.1016/j.tate.2008.04.008

Volkmann, M.J. and Anderson, M.A. (1997). Creating professional identity: Dilemmas and Metaphors of a first-year chemistry teacher, Science Education, 82(3), 293-310. Retrieved from https://doi.org/10.1002/(SICI)1098237X(199806)82:3<293::AID-SCE1>3.0.C0;2-7

Wenger, E. (1998) Communities of practice : learning, meaning and identity (Cambridge, UK, Cambridge University Press). Retrieved from https://doi.org/10.1017/CB09780511803932

Wenger, E. (1999) Communities of practice : learning, meaning and identity (Cambridge, UK, Cambridge University Press Retrieved from https://doi.org/10.1017/CB09780511803932

Zein, M. (2017). Professional development needs of primary EFL teachers : perspectives of teachers and teacher educators. Professional Development in Education Retrieved from https://doi.org/10.1080/19415257.2016.1156013 